\title{
Modernising THE CULTURAL LANDSCAPE
}

\section{Sverker Sörlin \& Christer Nordlund}

In the end, landscape turned out to be a concept almost entirely devoid of content. At worst a bad painting, at best a settled area, a stretch of native soil, in which the cooperative farmers' movement could mobilise support, or which it could protect, using arguments drawn from the cultural history of land cultivation. And then, gradually, but also instantaneously, the term passed through a developing tank, and out came a landscape that both unified and signified. At the end of the twentieth century the notion of landscape checked the divides that had deepened between tradition and modernity, among scientific specialities and among spatial practices. But it did so without the anti-modernism that in earlier periods had restrained the passion for landscape.

Landscape became flow, communication, context and the rehabilitation of the subject. For scholars, as well as writers and artists, the concept no longer stood for rural scenery, for vistas and villages, but for interaction, encounters between people and places. Landscape became a term that redefined "territory" at a time when states were fraying at the edges. Landscape became the common denominator for natural and cultural monuments: for the Grand Canyon as well as the Brooklyn Bridge. The word connected by a semantic thread the sublime and the commonplace, and we began to realise that it was not a question of cultural landscape and natural landscape, but of landscape tout court, simultaneously one and infinitely many.
This reawakened interest has opened up a great number of new perspectives on culture and place (Groth and Bressi 1997, Sörlin 2001 and 2002a). In this essay we intend to address the connection between modernism and landscape, using Sweden as a case. The traditional interpretation of Swedish modernism includes analyses of literature, art, sculpture, glass, architecture, photography, furniture and so on. A noteworthy contribution to our knowledge of this line of modernism was the exhibition in the Modern Museum in Stockholm and at the Bard Center in New York, Utopia and Reality: Modernity in Sweden, 1900-1960 (2000/ 2002). Sweden is also home to a large number of modernist social reformers, some of whom, notably Alva and Gunnar Myrdal, have 
96 won their places in an international Pantheon of modernizers (Sörlin 2002b).

But, we would like to argue, this understanding of modernism is too limited to encompass the 20th century experience in Sweden. Swedish modernism, in an almost literal sense, also reached out into nature, modernising landscape and creating new infrastructure as an integrated part of the general aesthetic and welfare ideas connected with modernism.

\section{Modernism}

Modernism in Sweden had a spatial dimension. We are thinking of the bridges, the power plants, the factories, the roads, the railroads and the power lines, the telegraph, radio and television installations - and everything else that make up the modern producti$v e$ landscapes of the past century. They were, many of them, shaped by modernism, and an articulation of modernism. But we are also thinking of the reproductive landscapes - national parks, nature reserves, theme parks, slalom slopes, camping facilities, golf courses, electrically lit trails for hiking and skiing, and so on.

These landscapes were equally modern, representing a modernising idea of the new citizen in the "Second New Nation" (Ruth 1984) - second only to the First New Nation, the United States. In the US, the role of the national vernacular landscape has been well articulated in the great tradition of historical landscape writing from John Brinckerhoff Jackson (1909-1996) to contemporaries such as John Stilgoe, Anne Whiston Spirn and Marc Treib (see Groth and Bressi 1997 for an overview).

We would like, however, for this essay on landscape modernization, to single out one work as a reference point: David Nye's American Technological Sublime (1994). Nye, a descendant of MIT's great landscape scholar and historian Leo Marx, has worked in Denmark for many years, which is perhaps why he is so perceptive of the sublime icons of water power stations, sky scrapers, railroads, fairs, and, ultimately, Las Vegas hotels - "the consumer's sublime".

Sweden cannot compete with the megalomania of Las Vegas, nor with the sheer scale of some of America's landscape icons. Yet, in many respects, there are interesting parallels between the kind of nature - embracing spatial modernism - that was produced in Sweden and the kind of technological monuments that David Nye presents. To illustrate this phenomenon our first example is the 1948 Borgafjäll alpine hotel in Lapland; designed by Ralph Erskine, an English-born architect who has worked most of his life in Sweden, and where he is still active at the age of 87 (Egelius 1988). The hotel is of a congenial design against the backdrop of Lapland's high mountains, and also very playful, with the roof like a ski slope. The background to Erskine's design was typically eclectic, not primarily Corbusier or Bauhaus, but rather a soft functionalism tempered by strong elements of a traditional Swedish provincial style. The province of Dalecarlia in his case, where the first sports cabins had been built by a well-to-do cultural Stockholm elite around 1900.

In the 1950s Erskine created an even grander encounter between modernism and nature in designing Kiruna, the Lapland mining town, which he envisioned as a BuckminsterFuller kind of realised Utopia, a 20th century sub-Arctic version of Renaissance Siena or Florence, complete with city walls, self suf- 


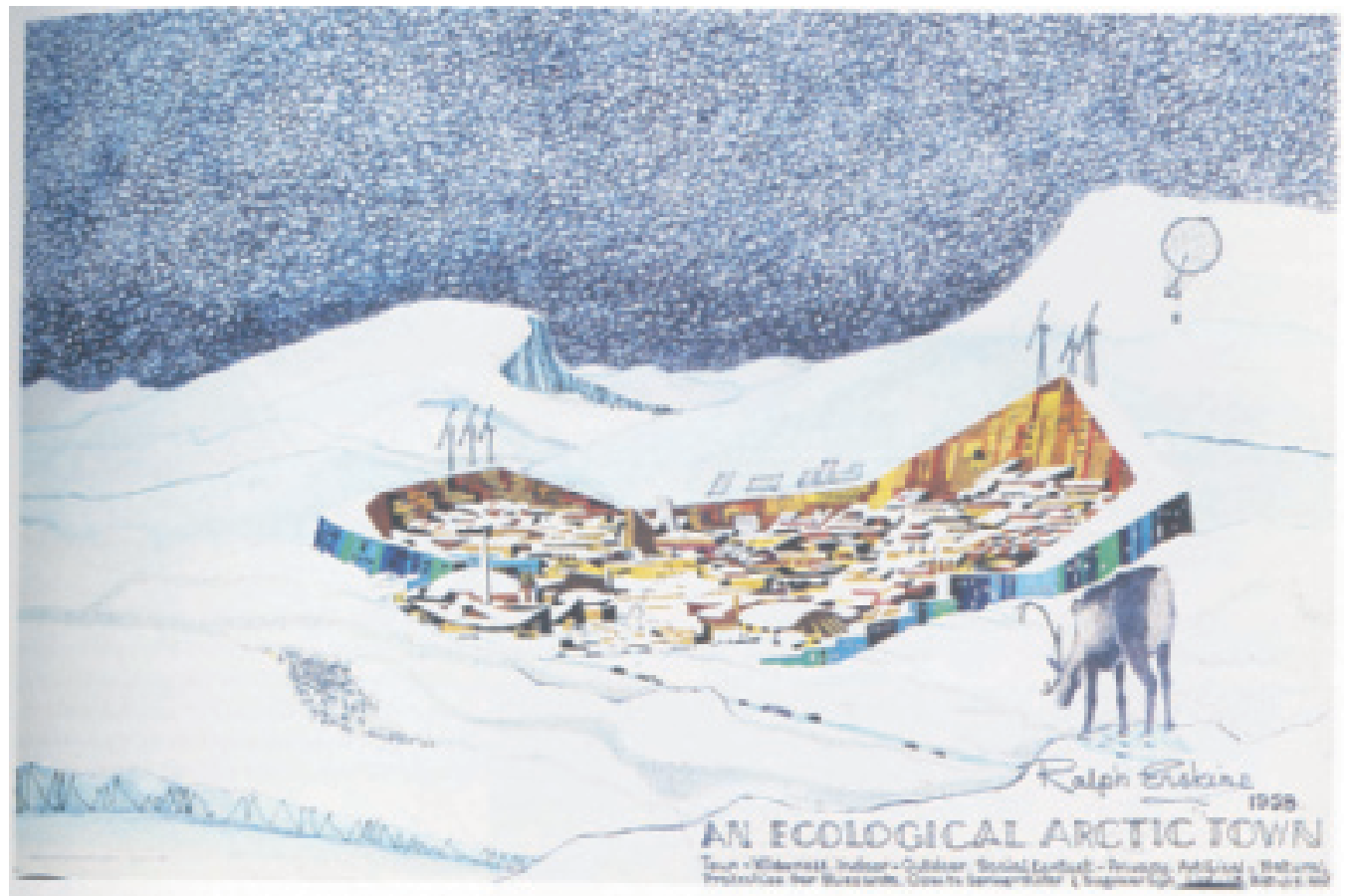

"An ecological arctic mining town". Ralph Erskine's design for Kiruna in 1958.

ficient regarding energy, yet connected to the world by cars and television. This is also Lewis Mumford, Swedish style.

Some of the style elements had been there in earlier art depicting Kiruna, as in paintings by Axel Törneman. But the most remarkable thing is that Kiruna's modernism became so pervasive. It is still today a modernist marvel, with private houses in happy colours and city hall by Arthur von Schmalensee. The mining company's corporate tower is part of the same ideal, in a constant dialogue with nature.

One should compare this with an almost contemporary building, one of the landmarks of Stockholm, the Wenner-Gren Centre from 1961, designed by Sune Lindqvist, and home for almost 40 years to the official scientific Sweden: research councils, committees, but also apartments and facilities for visiting scientists.

Close by was the contemporary Haga terminal, a stop on the bus or taxi trip from Stockholm city to Arlanda, the new airport, opened at about the same time. This was Swedish modern: a manifestation of scientists, rich industrialists, who had made their fortunes in the US - like Axel Wenner-Gren - and it all stood at the gateway to the world, happy to be seconded on the journey by blond SAS air stewardesses, in light blue uniform, who also featuried in the brochures of the Haga terminal (Lindqvist 1997). 
Sverker Sörlin \& Christer Nordlund

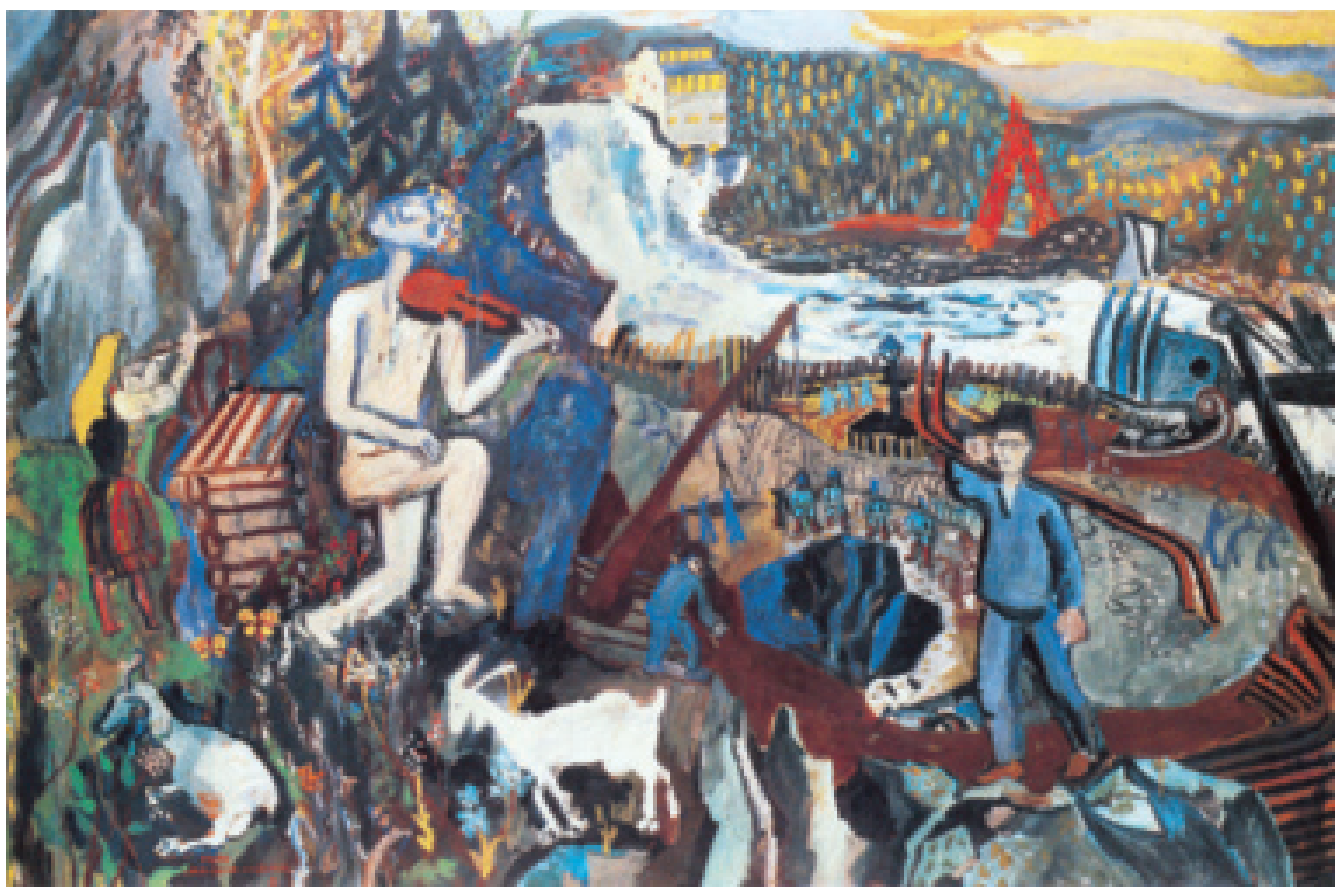

"Melodies on the riverside". Design for a tapestry by Sven Erixson in the 1950s. The Hammarforsen power station is seen in the background. The picture in Göteborgs konstmuseum.

\section{Hydroelectric DAMS}

AND ASSOCIATED BUILDINGS

Our second example is one of the most farreaching elements of the landscape in Sweden in the 20th century: hydroelectric power with its dams and buildings. Its construction was at times a hotly contested issue. Some can only see the lost rapids, and there is a whole iconography of devastation that has developed over a century. The hills that were created along the silenced rivers were called "Marion hills", after the enormous American machine which ate up stone and gravel and then deposited it on the riverside.

But in the early glory days of dam building there was much more enthusiasm. Mythology and the machine could meet, as in this modern expressionist classic by Sven Erixson, "the X" as he was commonly known. The wood sprite, the old herdswoman with her cattle and horn are the contemporaries of the new labour. And does not the "Marion" to the right have at least an eye, a sign of humanity? - although one can also think of the dinosaurs, with badly adapted technology.

In the first decades of the 20th century a romantic, nationalist idiom dominated the water power stations. There was something sacred, even mysterious, about this magic source of energy that sought its architectural expression in the religious sphere, such as the 


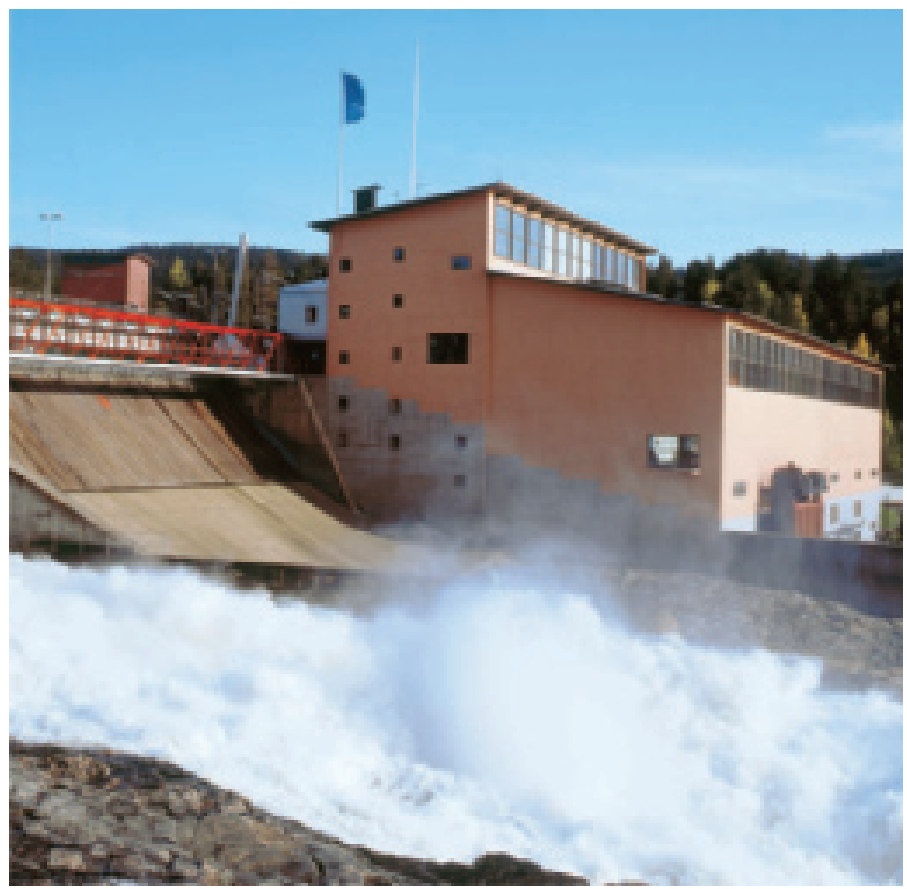

The Hammarforsen power station in the Indalsälven river. Designed by Osvald Almqvist 1926-27. Photo by Lasse Brunnström 1992.

massive plant, reminiscent of a Roman church, in Glomfjord, Norway, initially a Swedish project but ultimately designed by the Norwegian architect Olaf Nordhagen. It was later, in the 1920s and, particularly, in the 1930s, that clear modernist design concepts entered this solidly nationalist genre of buildings, and then it was in form a remarkably early sign of modernism in Sweden. In fact, the modernising tendencies started beyond the city boundaries, in remote and rugged wilderness.

Erik Hahr designed the power plants at Vargön and Stadsforsen in the 1930s (Brunnström 2001). Earlier still Osvald Almqvist had worked on projects in the Dalalven river in the early 1920s, but these did not yet display the radical simplicity and the typical flat roofs that he would later use. However in 192930 the time was ripe for his functionalist designs for the power plants at Krångfors and Hammarforsen. In 1929 Almqvist published the only comprehensive work to date in Swedish on the aesthetics and architecture of hydroelectric power plats, Recent Hydro-electric Installations - the title was about as mundane as the content.

Almqvist's approach was the model for the future, although in 1929 he was in fact too early; he had problems getting new commissions, and he waged a protracted fight over his honorarium in one case. Only in 1948, 
Sverker Sörlin \& Christer Nordlund

100

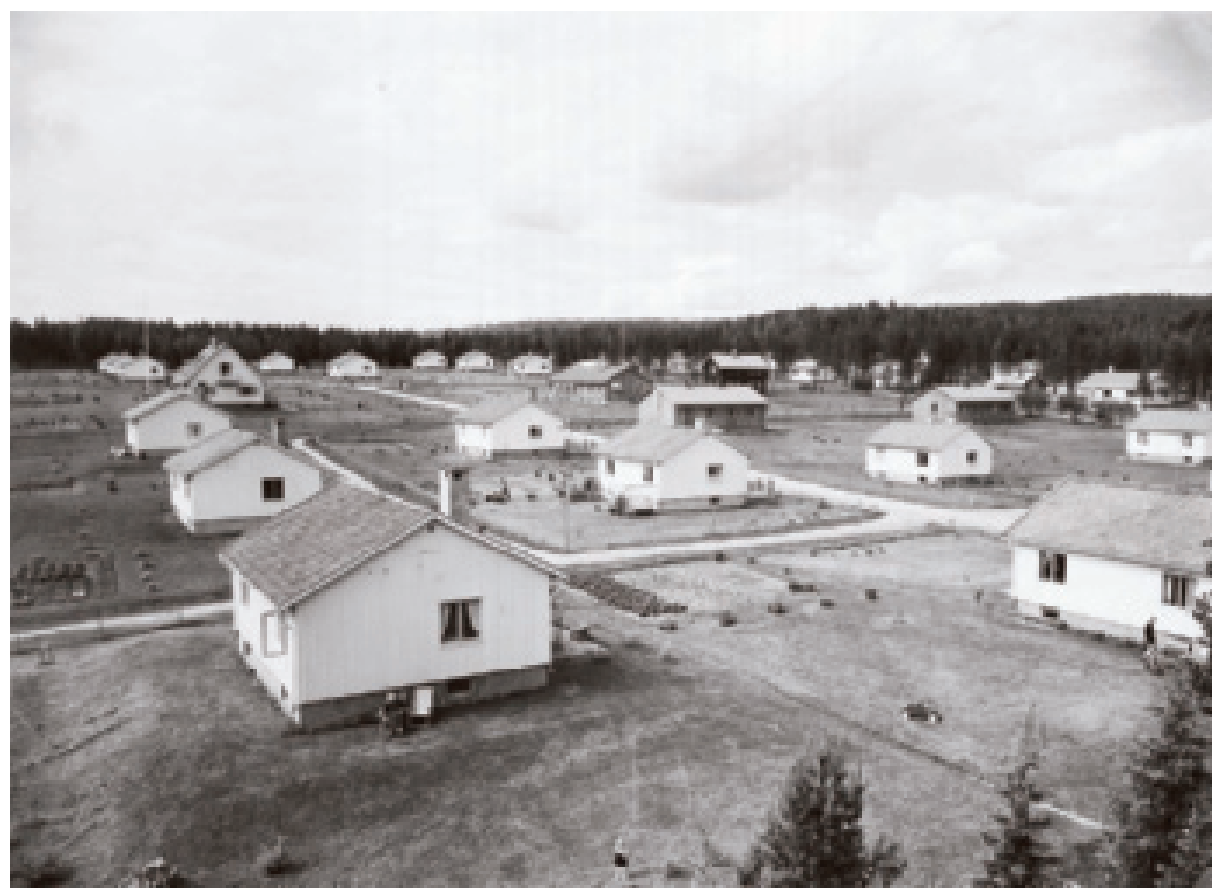

Housing complex for the workers at Storfinnforsen in the Faxälven river. Early 1950s. Photo in the archives of Krangede $A B$, Östersund.

shortly before his death and a full 16 years after the work was completed, did he finally receive part of his money. The reason: he had refused to compromise on some of his basic functionalist principles and opted not to satisfy the traditionalist impulses of those who gave him the commission.

And in a certain sense he committed a kind of commercial suicide for the entire architectural profession when it came to water building. Large-scale water installations for timber floating or even bridges used to be chiefly the work of engineers in Sweden. Then architects came to the fore with the power plants, which were considered important enough, almost "national", to merit more elaborate design. Reducing the style to clean functionalism and simple geometries seemed to the industry to be creating a contradiction in terms, and they called out once again: let us use engineers!

As the buildings grew more stereotyped in the 1940s and 50s and even more so in the 1960s and 70s interest turned instead to the landscape, and more generally to the entire context of the installation. Part of that context was social, and with welfare ideology quickly gaining ground, large-scale infrastructure were not allowed to be an exception. Housing, hygiene, schools and recreation became parts of the projects - and certainly marked their place in the landscape, as can be 


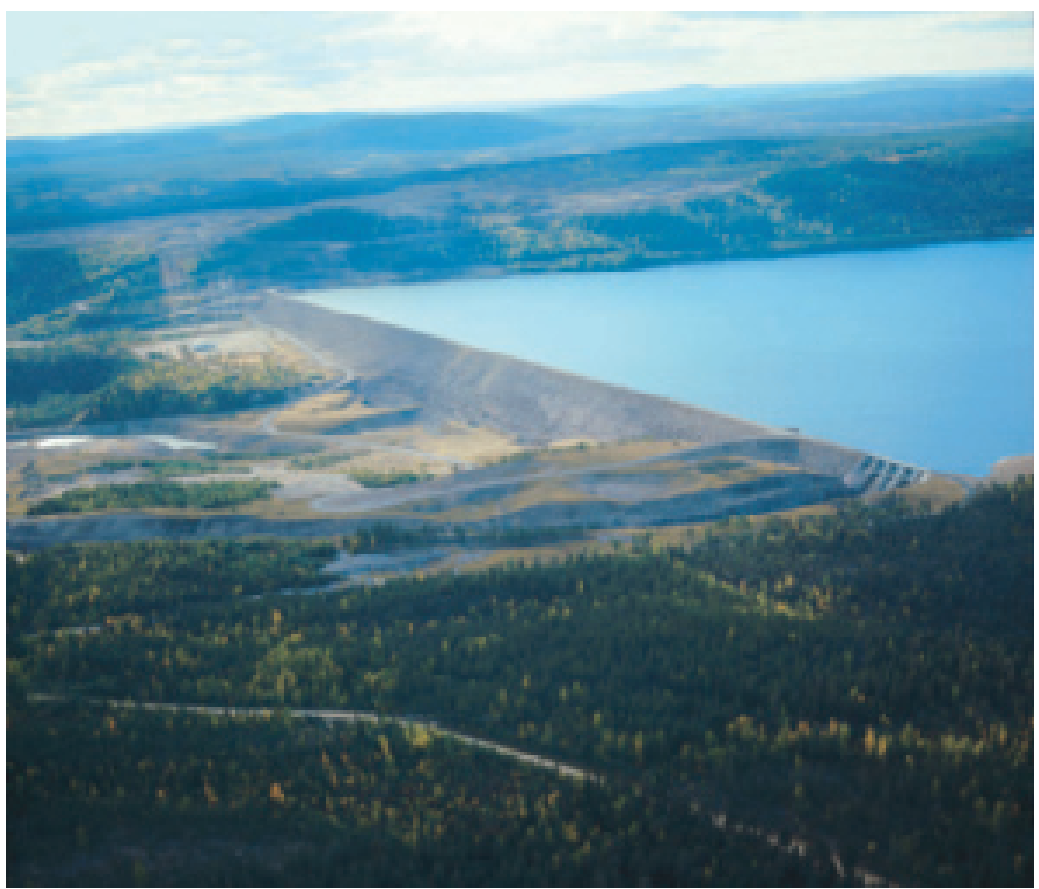

The Messaure dam constructed between 1957 and 1963. Landscape planning by Erik Lundberg. Photo by Gunnar Bergbom 1970.

seen from the housing complexes that were built at Storfinnforsen in the Faxälven river in the 1950s, and their many parallels (Pettersson \& Sundin 2002). This is standardised architecture - the whole point is to see it as the grander, landscape version of modernism we are talking about here - a modernism talking to mountains, forests and rivers.

In the 1940s Sigurd Curman, the former Director of the National Board of Antiquities, started to work as a consultant to the state-owned "Waterfalls" company (Vattenfall). The state pensioner worked diligently to restore and adjust after the actual building process. He advised on aesthetics, on land- scaping, he even suggested colours for the flowers plantated by the staff houses; it was all quite moving.

But the more he saw of the engineerings and their true nature the more he opposed what they did. He also seems to have realised that what he could do was of a cosmetic nature. His own background in cultural history also made him basically opposed to a modernist approach. He was truly sad when old agrarian landscapes, not to mention pagan hunting symbols carved in the granite, just had to go in the name of progress (Nilsson 1988).

Far more intriguing, therefore, is the work of Erik Lundberg, who replaced Curman in 1953 as the Waterfall company's consultant. 
102 He had started out as Curman's assistant at the National Board but in this new role he took an entirely different direction from his predecessor.

Lundberg's approach was an articulate landscape modernism. He advocated change, he did not try to hide the cuts and scars in nature - he openly declared them to be true and rational. $\mathrm{He}$ aestheticized what was in essence engineering economics: angles for transportation vehicles, slopes for gravel stone and landfill. He made a virtue out of volume, one of the most visible projects was the Stornorrfors power plant in the Umeå river local farmers were surprised to see majestic new hills emerging in the flat landscape.

Perhaps the most striking example of Lundberg's production was Messaure, an enormous Lapland dam and reservoir. The bottom line was: do not conceal! Lundberg's instructions abound with phrases such as: "stand in contrast to", and (our favourite) "remain strict and sterile". The Messaure dam should under no circumstances be regained by nature. There was to be no topsoil on the stone slopes. This was a monument for future generations to worship, "a sight of dignity" (Brunnström 2001, 258).

\section{Traditional Swedish landscape}

The old national landscape of Sweden emphasized the features that modernism threatened: the rural countryside, the wild and spectacular scenery of Lapland's mountains, river rapids, classical provinces such as Dalecarlia and Scania, each with their own folklore and costume to go with the scenery. A new secular religion was born: the cult of this landscape.

Locations for skiing, alpine walks, swimming, sailing and forest outings gradually achieved status as national nature sanctuaries. This was particularly the case in Sweden, where a number of national and local trekking and tourist associations were born to cater to the growing interest. But in other parts of, especially northern, Europe there was also a rapidly growing feeling for the non-urban landscape, the highlights of which tended to replace the churches as destinations for Sunday walks. Holmenkollen, a recreational area near Oslo, can be seen in this light, and it is remarkable how local and regional open-air museums took on the function of national sites of worship. In Sweden, the open-air museum of Skansen was created in the $1890 \mathrm{~s}$ to serve as a symbol of Swedish natural and cultural heritage (Sörlin 1998, Rantatalo and Åkerberg 2001). Further away from Swedish cities, a whole infrastructure of wilderness accessibility and worship developed, replete with lookout towers, overnight cottages, and "tourist stations" (Pihl Atmer 1998, Sandell and Sörlin 2000).

National landscapes were codified in works, often intended for the schools, such as the reader Folkskolans läsebok (a school reader used from 1868 for almost a full century) and The Wonderful Adventures of Nils (1906-07), Nobel laureate Selma Lagerlöf's classic epic of the little boy Nils and his travels across Sweden from south to north riding on the back of a goose. The landscape images thus produced, and reproduced, made up a natural heritage (naturarv; Hillmo 1990, Nordlund 2001), as important as the cultural heritage, and indeed part and parcel of the latter.

This traditional landscape - shunning the urban, an infrastructure, and the modern has, by and large, lingered on. It is still present as we enter a new century, and it is long since the principal battles between industrial 
modernity and pristine or pastoral landscapes were fought (Haraldsson 1987, Sörlin 1988). Yet, at the same time, the Swedish national landscape has undergone a modernization that merits further understanding and that should also lead to an adjusted selfimage of the nation. The connection with avant-gardism and urbanity, which is often readily to hand in the analysis of Swedish modernism, should not be taken for granted. The form and language of modernism, and its social and technological ambitions, are geographically wide-ranging; they cover the entire country.

The spatial modernism also had its sociological points. There were alliances built between provincial enthusiasts and modernizers that in a somewhat paradoxical way contributed to the reshaping of landscape. This was manifested through the "Samfundet för hembygdsvård", an association for landscape design and care. The Association was founded in 1916 and the Royal School of Technology was one of its foremost anchoring points. The Association was founded by architects and hailed progress and landscape change. The "care for the homestead" was not intended to question modernization but to make change aesthetically acceptable.

What the Association did was to legitimize a modernist redesigning of landscape in Sweden. Road consultants and other specialists, employed by the Association, served as counsellors for communities and road administration authorities. The Association counselled on quarries, mines, factories, airports and other large-scale projects, and on power plants in the rivers as well. Remarkably often the message was not to doubt the new man-made landscapes. Gravel hills, remnants from mining, artificial riverbeds - these were brave and beautiful contours in the landscape, enhancing its interest (Björkroth 2001).

Thus another trait was included that had been part of Swedish modernism from the beginning: a cultivation of taste. This cultivation was intended to make people accept and acclaim that which they could not be expected to like. These ideas were now, in the midwar period, articulated from the political left (Hirdman 1989), not from the old conservative elite, which was rather sceptical about modernism.

It is important to underline this infrastructural, spatial, dimension of Swedish modernism, not least because it can help us to escape from a false contradiction that is too often present in the understanding of modern Sweden: that between nature and culture, or between a romantic backward-looking sentimentality, directed towards the landscape and the peripheries, and a rationalistic futureoriented vision directed towards the cities, the "edge cities" (although the term came later; see Garreau 1992), the commuter trains, and the modernist-functionalist monuments, such as Bromma airport in Stockholm or the quintessential modernist showcase, the Helsingborg exhibition of 1955 .

\section{A MAJOR MISSIONARY GESTURE OF MODERNISM}

It was not so: the direction of modernism was just as peripheral, reaching outward from the large urban centres, out to the smaller municipalities and landscapes in a major, missionary gesture. Indeed, it was often already there. Some of the most realized modernist Utopias were to be found in the small company towns, or in the temporary communities, arranged around building sites and power 
104 plants, or in lumber camps in the forests. It is of this general historical movement that Kiruna (above) constitutes the classical masterpiece (Brunnström 1980-81), iron mountains and Erskine architecture under a constant state of change into art and landscape.

The features that we have discussed here ordinary Swedish landscapes in a period of modernism - are cultural milieux. The heritage industry and the cultural protection authorities, notably the National Board of Antiquities, have, formally, been assigned the task of recognizing this multidimensional modernization of landscape and the continuous flowing (re)construction of new landscapes, modern or post modern. But the general impression is rather that the conservation professionals have some difficulty in handling in their practice the plenitude of usage and forms of landscapes that exist.

To this problem is added the issue of social involvement. A democratically determined heritage can not disregard the processes by which values are formed. Rather, it is a question of which processes are used and which values are formed. The sites, monuments, and landscapes that were constructed to make up the pasts of the past are not necessarily the only options for the pasts of the future. There should be different memories to reveal, other places to remember, and new objects to discover from which to construct a new heritage - memories, places, and objects that stand in new relationships to citizens and communities.

\section{A MODERNIZED}

\section{NATIONAL LANDSCAPE}

We have dealt here primarily with non-urban landscapes of infrastructure - a moder- nized national space - but the argument could also apply to urban environments. For the past quarter century, or more, the spatial restructuring of cities in the United States, Europe, and elsewhere has been characterized by a conscious avoidance of modernism. Instead, a retrospective, nostalgic version of an early industrial aesthetic and scale has guided architects, planners, and designers, very much as the provincial landscapes dominated the national landscape of the early industrial period. In an explicit effort to "invent" places and raise real estate values, there has been a packaging of space and a commodification of history. This history has appeared in allusions and reconfigurations rather than in any concerted ambition to employ history as a tool for collective understanding, or as a fabric with which to organize the city and its citizens into a meaningful whole, travelling together through time (Boyer 1996, Sörlin 1999).

"Cultural heritage" is a contested concept, as is the concept of landscape. It can be given an expansionist definition, including almost anything, ending up in an "additive" heritage where the landscapes and monuments of an ever-increasing number of different ethnic groups, classes, regions, or other entities are included. Or it can be interpreted in a more restrictive way, in the singular, referring to the National heritage, thereby gaining an exclusive function.

It is time to ask what is sustainable in these notions of heritage, preservation and landscape. The landscape that is growing around us needs to be valued, preserved, cared for and used. But above all it needs acknowledgement. Landscape per se, is different from that which is granted status as cultural heritage or by preservation biologists. A deeper reflection 
on the landscapes that we actually live in could contribute to new ideas about landscape care and use, which are needed to replace the current practice. In these new ideas boundaries between different types of landscapes will probably be less absolute, status more relative and negotiable, territorial entities more plural, and citizens more involved in the value formation of landscapes. As for Sweden, however, a first step would be to reconsider the role of modernism in the formation of the national landscape. Paradoxically, in the Second New Nation, that has yet to happen.

\section{Note}

- The article is a product of the the research programme "Landscape as Arena: Science, Institutions, and the Environment, 1800-2000", sponsored by the Bank of Sweden's Tercentenary Fund.

\section{Works Cited}

Björkroth, Maria, Hembygd i samtid och framtid 1890-1930: En museologisk studie av att bevara och förnya (Umeå: Umeå University, 2000).

Boyer, M. C., The City of Collective Memory: Its Historical Imagery and Architectural Entertainments (Cambridge, MA: MIT Press, 1996).

Brunnström, Lasse, Kiruna - ett sambällsbygge i sekelskiftets Sverige, 2 vols. (Umeå: Umeå University, 1980-81).

—, Estetik \& ingenjörskonst: Den svenska vattenkraftens arkitekturhistoria (Stockholm: The National Board of Antiquities, 2001).

Egelius, Mats, Ralph Erskine, arkitekt (Stockholm: Byggförlaget, 1988).

Friluftshistoria: Från 'härdande friluftslif' till ekoturism och miljöpedagogik, eds. Klas Sandell and Sverker Sörlin (Stockholm: Carlssons, 2000).

Garreau, Joel, Edge City: Life on the New Frontier
(New York: Anchor Books, 1992).

Groth, Paul and Todd W. Bressi, eds. Understanding Ordinary Landscapes (New Haven, CT \& London: Yale University Press, 1997).

Haraldsson, Désirée, Skydda vår natur!: Svenska Naturskyddsföreningens framväxt och tidiga utveckling (Lund: Lund University, 1987).

Hillmo, Thomas, "Det svenska naturarvet." Tvärsnitt 1990.

Hirdman, Yvonne, Att lägga livet till rätta: Studier $i$ svensk folkhemspolitik (Stockholm: Carlssons, 1989).

Lindqvist, Svante, "Forskningens fasader: WennerGren Center som symbol för svensk vetenskap." Lychnos 1997.

Nilsson, Kjell, Industri möter landskap: Visuella aspekter på utformning och inplacering av industriella ingrepp i landskapet (Alnarp: Swedish Agricultural University, 1988).

Nordlund, Christer, Det upphöjda landet: Vetenskapen, landhöjningsfrägan och kartläggningen av Sveriges forflutna, 1860-1930 (Umeå: Royal Skytte Society, 2001).

Nye, David, American Technological Sublime (Cambridge, MA \& London: MIT Press, 1994).

Pettersson, Richard and Bosse Sundin, Sigurd Curman, Nämforsen och det kultiverade kraftverket (Umeå: Umeå University, 2002).

Pihl Atmer, Ann Katrin, Livet som levdes där måste smaka vildmark: Sportstugor och friluftsliv 1900 1945 (Stockholm: Stockholmia, 1998).

Rantatalo, Petra and Sofia Åkerberg, ”'Ansikte mot ansikte med de verkliga tingen': Folkskolans åskådningsundervisning, Skansen och den nya nationalismen." Lychnos 2001.

Ruth, Arne, "The Second New Nation: The Mythology of Modern Sweden." Daedalus 1984.

Sörlin, Sverker, Framtidslandet: Debatten om Norrland och naturresurserna under det industriella genombrottet (Stockholm: Carlssons, 1988).

_, " 'Att skapa traditioner som aldrig öfvergifvas': 
106 Artur Hazelius och det nationella arvet under 1800-talet", In: Att forma bilden av den svunna tid: Nordiska museet i den svenska kulturhistorien. En bok om Nordiska museet under 125 år, eds. Elisabeth Hidemark and Bengt Nyström (Stockholm: The Nordic Museum, 1998).

—, "The Modern Vision and Its Critics." In: Vision and Reality: Social Aspects of Architecture and Urban Planning in the Modern Movement, ed. M. Botta (Stockholm: DOCOMOMO and Swedish Museum of Architecture, 1999).

—, "The Trading Zone between Articulation and Preservation: Production of Meaning in Landscape History and the Problems of Heritage Decision-making." In: Rational Decision-making in the Preservation of Cultural Property, eds. N. S. Baer and F. Snickars (Berlin: Dahlem University Press, 2001).

—, [2002a], "Can Places Travel?.” In: Dokumenta 11: The Exhibition: Catalogue, ed. Okwui Enwezor (Ostildern-Ruit: Hatje Cantz, 2002).

—, [2002b], "Prophets and Deniers: The Idea of Modernity in Swedish Tradition." In: Utopia and Reality: Modernity in Sweden 1900-1960, ed. Cecilia Widenheim (New Haven, CT \& London: Yale University Press, 2002).
Understanding Ordinary Landscapes, eds. Paul Groth and Todd W. Bressi (New Haven, CT \& London: Yale University Press, 1997).

Utopia and Reality: Modernity in Sweden 1900-1960, ed. Cecilia Widenheim (New Haven, CT \& London: Yale University Press, 2002).

Sverker Sörlin holds the Chair of Environmental History at Umea University, Sweden, and a long-term position as visiting professor in the section for History of Science and Technology at the Royal School of Technology in Stockholm, where he is also the director of the Swedish Institute for Studies in Education and Research (SISTER).

Adr. Institutionen för historiska studier, Umeå Universitet, S-90187 Umeå

E-mail:sverkers@sister.nu

Christer Nordlund holds a Ph.D. in History of Science and Ideas from Umea University, Sweden, where he works as an assistant professor.

Adr. Institutionen för historiska studier, Umeå Universitet, S-90187 Umea

E-mail: christer.nordlund@histstud.umu.se 